\title{
Atmospheric emissions from electric energy generation and their impact on environment, and the potential of renewable energy sources in Italy
}

\author{
Tong Wang ${ }^{1, a *}$, Longmiao Yuan ${ }^{2}$, YingqinWu ${ }^{2, b *}$ \\ ${ }^{1}$ School of Engineering, Newcastle University, Newcastle, NE1 7RU, UK \\ ${ }^{2}$ Key Laboratory of Petroleum Resources, Gansu Province / Northwest Institute of Eco-Environment and Resources, Chinese Academy \\ of Sciences, Lanzhou 730000, PR China
}

\begin{abstract}
The European Union has set targets to reduce greenhouse gas emissions in total energy consumption, ensure the development and use of clean energy sources, and strive to reduce carbon emissions by $90 \%$ from 1990 levels by 2050 . This study attempts to assess the environmental impact of electricity production on electricity demand and associated emissions in Italy through a three-step process. First, a literature review was conducted to estimate the growth of electricity demand in Italy by population and industry in 2014. Secondly, the $\mathrm{CO}_{2}$ and $\mathrm{SO}_{2}$ produced in the process of power generation by different power production methods were evaluated and compared. Finally, according to the current production and power models, the development trend of renewable energy in Italy in 2050 was estimated, and the satisfactory conclusion is that the renewable energy can fully meet the supply and demand in 2050 in Italy.
\end{abstract}

\section{Introduction}

Most of the current electric energy production methods cause adverse environmental impacts [1-4]. Under the pressure of increasing environmental protection standards, it is imperative for power plants to improve their efficiency and environmental performance. The European Union (2009) [5] has targeted a $20 \%$ reduction in greenhouse gas (GHG) emissions by 2020 from the 1990 levels, and renewable energy production is deemed the key solution. As a result, there is widespread enthusiasm for renewable energy production.

According to 2014 data, Italy has a population of $60,789,140$ and a total surface area of $301,340 \mathrm{~km} 2$ (including inland water bodies and some coastal waters). Forest area and agricultural land account for $31 \%$ and $45 \%$ of the land area respectively. Due to the large vertical extension of the peninsula and the fact that the mountains are mostly internally formed, Italy has an extremely diverse climate and has strong solar radiation. Average winter temperatures range from $0^{\circ} \mathrm{C}$ to $12^{\circ} \mathrm{C}$ and in summer from $20^{\circ} \mathrm{C}$ to over $25^{\circ} \mathrm{C}$.

Italy is a highly developed country with a high human development index of approximately 0.892 . The total GDP is approximately $\$ 2.159$ trillion and the GDP per capita is approximately $\$ 35,518$. However, there is a large gap between the standard of living and the economy between the North and the South. Italy is highly industrialised and a leader in world trade and exports. The country's economy is dominated by commerce, agriculture and the influential high-quality automotive, machinery, food, design and fashion industries.

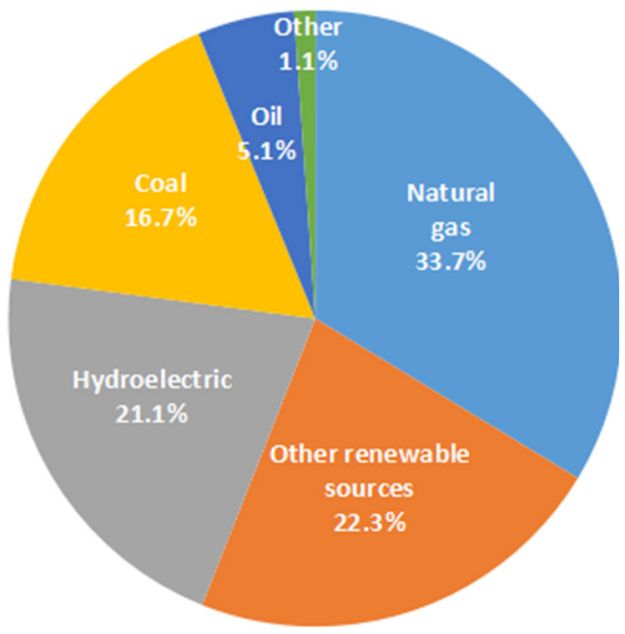

Fig 1. Electricity production and sources in Italy in 2014

Electricity is available to everyone in Italy, with a per capita consumption of approximately 5,002.4 $\mathrm{kWh}$. Figure 1 shows the forms of electricity generation and their contributions. Natural gas accounted for $33.7 \%$ of Italy's total electricity generation. This is followed by renewables, with hydroelectricity accounting for $21.1 \%$ and the remaining renewables accounting for $22.3 \%$. Coal and oil generated less electricity, accounting for $16.7 \%$ and $5.1 \%$ of total production respectively. Italy has been without nuclear energy since 1987. Italy's potential for electricity production from renewable sources has been on the rise and government incentives for renewable energy

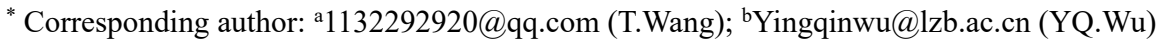


have stimulated emerging renewable energy production capacity [6-7].

\section{Methodology and calculation of $\mathrm{CO}_{2}$ and $\mathrm{SO}_{2}$ emissions}

Coal has a calorific value of $23,000 \mathrm{~kJ} / \mathrm{kg}$, a carbon content of $670 \mathrm{~g} / \mathrm{kg}$ and a sulphur content of $20 \mathrm{~g} / \mathrm{kg}$. Oil has a calorific value of $44,000 \mathrm{~kJ} / \mathrm{kg}$, a carbon content of $850 \mathrm{~g} / \mathrm{kg}$ and a sulphur content of $1 \mathrm{~g} / \mathrm{kg}$. Natural gas has a calorific value of $38,000 \mathrm{~kJ} / \mathrm{m}^{3}$, a carbon content of 536 $\mathrm{g} / \mathrm{m}^{3}$ and a sulphur content of $5.5 \mathrm{mg} / \mathrm{m}^{3}$.

Calculate the mass of each element contained per kJ of calorific value:

$$
C / S(g / k J)=\frac{\text { Element content }}{\text { Calorific value }}
$$

The efficiency of converting the thermal energy of fuel combustion to electrical energy is $34 \%$.

Then the mass of elements per $\mathrm{kWh}$ is:

$1 \mathrm{kWh}=3600 \mathrm{~kJ}$

$$
C / S(g / k W h)=\frac{C / S(g / k J) \times 3600 \mathrm{~kJ} / \mathrm{kWh}}{0.34}
$$

It is assumed that $100 \%$ of the carbon and sulphur in the fuel is oxidised to $\mathrm{CO}_{2}$ and $\mathrm{SO}_{2}$ and the effect of emission contol technology is ignored.

So the emissions per kWh of fuel:

$\mathrm{CO}_{2} / \mathrm{SO}_{2}(\mathrm{~g} / \mathrm{kWh})=\frac{\mathrm{C} / \mathrm{S}(\mathrm{g} / \mathrm{kWh}) \times \text { Molecular weight }\left(\mathrm{CO}_{2} / \mathrm{SO}_{2}\right)}{\text { Atomic weight }(\mathrm{C} / \mathrm{S})}$

The total amount of electricity generated from fuel combustion:

Electric power consumption $\times$ Percentage of electricity produced from fuel combustion $\%$ 1 - Electric power transmission and distribution losses\%

Then the total emissions of $\mathrm{CO}_{2}$ and $\mathrm{SO}_{2}$ are:
Emissions per $\mathrm{kWh}$ of fuel $\times$ Electric power consumption from fuel.

\section{Results and discussions}

\subsection{Contribution of different electricity production methods to $\mathrm{SO}_{2}$ and $\mathrm{CO}_{2}$ emissions}

As can be seen from Table 1, Italy's per capita emissions of $\mathrm{CO}_{2}$ and $\mathrm{SO}_{2}$ were greater than the world's per capita emissions. The total emissions of $\mathrm{CO}_{2}$ and $\mathrm{SO}_{2}$ were $4.406 \times 10^{11} \mathrm{~kg}$ and $1.758 \times 10^{9} \mathrm{~kg}$ respectively, both accounting for around $1.1 \%$ of the world's total emissions. In terms of emissions, the most polluting fuels were, in descending order, coal, oil and natural gas (Figure 2). However, oil has a higher calorific value than natural gas and coal has the lowest. Natural gas contains less carbon than other fossil fuels. Besides, natural gas power plants are technically and economically flexible, so they can respond quickly to peaks in demand and match intermittent renewable such as wind power.

Table1. $\mathrm{CO}_{2}$ and $\mathrm{SO}_{2}$ emissions per capita and total emissions in Italy and the world in 2014.

\begin{tabular}{|c|c|c|c|c|}
\hline $\begin{array}{c}\text { Pollutant } \\
\text { emission }\end{array}$ & $\begin{array}{c}\text { Emissions } \\
\text { per capita } \\
\text { in Italy } \\
(\mathrm{kg})\end{array}$ & $\begin{array}{c}\text { Emissions } \\
\text { per capita } \\
\text { in Italy } \\
(\mathrm{kg})\end{array}$ & $\begin{array}{c}\text { Total } \\
\text { emission } \\
\text { in Italy } \\
(\mathrm{kg})\end{array}$ & $\begin{array}{c}\text { World } \\
\text { total } \\
\text { emission } \\
(\mathrm{kg})\end{array}$ \\
\hline $\mathrm{CO}_{2}$ & 7247.23 & 5439.40 & $\begin{array}{c}4.406 \\
\times 10^{11}\end{array}$ & $\begin{array}{c}3.946 \\
\times 10^{13}\end{array}$ \\
\hline $\mathrm{SO}_{2}$ & 28.92 & 21.71 & $\begin{array}{c}1.758 \\
\times 10^{9}\end{array}$ & $\begin{array}{c}1.575 \\
\times 10^{11}\end{array}$ \\
\hline
\end{tabular}

Table2. Scenarios for $100 \%$ renewable energy by 2050 .

\begin{tabular}{|c|c|c|c|c|c|}
\hline Energy types & Hydroelectricity & Geothermal power & Solar power & Wind power & $\begin{array}{c}\text { Total electricity } \\
\text { generation }\end{array}$ \\
\hline $\begin{array}{c}\text { Electricity } \\
\text { generation }\end{array}$ & $6.5 \times 10^{10} \mathrm{kWh}$ & $5.66 \times 10^{9} \mathrm{kWh}$ & $8 \times 10^{10} \mathrm{kWh}$ & $\begin{array}{c}4.93 \times \\
10^{10} \mathrm{kWh}\end{array}$ & $2 \times 10^{11} \mathrm{kWh}$ \\
\hline Total percentage of & $32.5 \%$ & $2.83 \%$ & $40 \%$ & $24.67 \%$ & $100 \%$ \\
\hline
\end{tabular}

The use of fossil fuels can cause serious environmental problems. The large amounts of $\mathrm{CO}_{2}$ produced by combustion contribute to global warming [810]. Greenhouse gases such as $\mathrm{CO}_{2}$ absorb the infrared radiation emitted by the earth and re-emit some of it to the surface, thus accelerating climate change. The continued rise in global temperatures will have further adverse effects on ecosystems and humans, and the WMO has stated that climate change is the greatest threat to human health in the 21 st century [11]. $\mathrm{SO}_{2}$ from burning is a pungent, toxic gas that can cause respiratory problems. Also, $\mathrm{SO}_{2}$ combines with smoke particles and has a synergistic effect on the respiratory system (bronchitis). When $\mathrm{SO}_{2}$ is released into the atmosphere, it will slowly be oxidized to $\mathrm{SO}_{3}$ in the presence of solar radiation. $\mathrm{SO}_{3}$ acts as a secondary air pollutant and causes acid rain problems. Depending on the local geology, this can lead to acidification of soils and lakes [12-14]. To mitigate the negative effects of fossil fuels, alternative energy sources (e.g. renewable energy) should be used. 


\section{$3.2100 \%$ renewable energy generation programme}

Around 55.5\% of Italy's electricity in 2014 was produced by burning fossil fuels. Assume that by 2050, all of Italy's electricity needs will be generated from renewable sources, mainly solar, wind, hydro and geothermal power. Jacobson et al. (2015) [15] assumed that because electric motors are much more efficient than internal combustion engines, Italy will end up using about $34 \%$ less electricity demand when all electricity is generated using renewable energy sources. Based on Italy's total electricity consumption in 2014, the total electricity consumption in 2050 would be approximately $2 \times 10^{11} \mathrm{kWh}$. The scenario of $100 \%$ renewable energy by 2050 is shown in Table 2 .

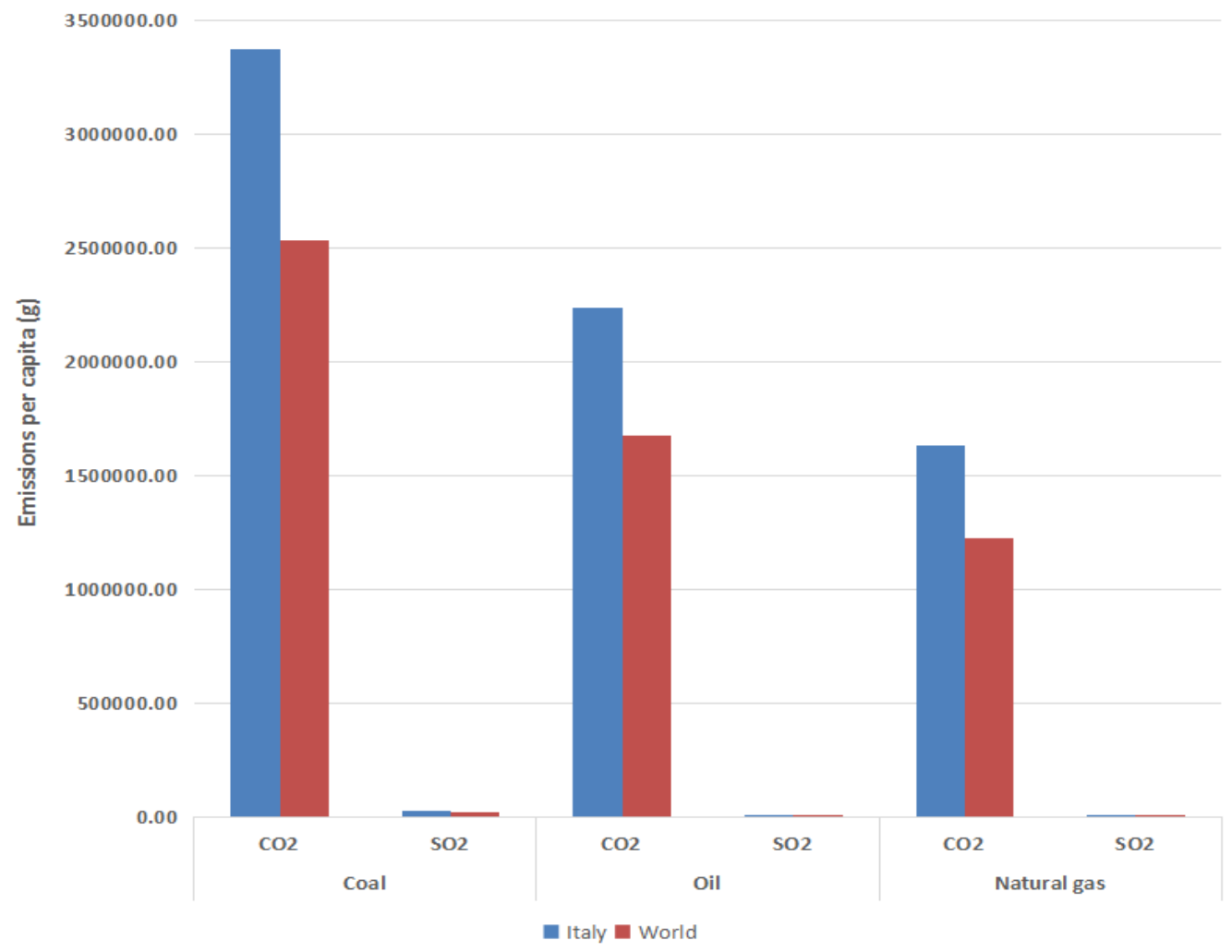

Fig 2. Contribution of different electricity production methods to $\mathrm{SO}_{2}$ and $\mathrm{CO}_{2}$ emissions per capita for Italy and the world in 2014.

\subsection{Hydroelectricity}

The storage capacity and rapid response characteristics of hydropower are particularly valuable in meeting sudden fluctuations in electricity demand and matching supply from less flexible sources of electricity and variable renewable energy sources such as solar photovoltaic and wind power.

According to calculations, the hydropower potential on Italian territory is about $65 \mathrm{TW}$ (Web.archive.org. 2012) [16], which in 2014 was already $98 \%$ developed, almost reaching the limit of maximum possible exploitation. It is therefore not a form of power generation that can be further developed. The most favourable, technically and economically convenient sites have already been exploited and there are many technical, environmental and economic obstacles to building new large reservoirs and large power plants. The future of hydropower in Italy is therefore limited to the construction of low power $(<100 \mathrm{~kW})$ micro-hydro plants (GSE 2011) [17].

\subsection{Geothermal power}

Geothermal energy is considered a sustainable and renewable source of energy as it is extracted in small quantities compared to the heat content of the earth. The greenhouse gas emissions from geothermal power stations average $45 \mathrm{~g}$ of carbon dioxide per kilowatt-hour of electricity, less than $5 \%$ of conventional coal-fired power plants. In 2015, the total electricity generated from geothermal energy in Italy was 5,660 GWh. Assuming the production of geothermal energy is remain constant in 2050.

\subsection{Geothermal power}

Geothermal energy is considered a sustainable and renewable source of energy as it is extracted in small quantities compared to the heat content of the earth. The greenhouse gas emissions from geothermal power stations average $45 \mathrm{~g}$ of carbon dioxide per kilowatt-hour of electricity, less than $5 \%$ of conventional coal-fired power plants. In 2015, the total electricity generated from geothermal energy in Italy was 5,660 GWh. Assuming the production of geothermal energy is remain constant in 2050 . 


\subsection{Solar power}

According to the Global Solar website [18], the minimum amount of direct normal solar energy in Italy is 2.3 $\mathrm{kWh} / \mathrm{m}^{2}$, which generates $6.77 \times 10^{11} \mathrm{kWh}$ of electricity, a value far greater than Italy's total electricity needs, so the potential for solar power is very high. If solar power will be used to generate $40 \%$ of the total electricity generated in $2050,34783 \mathrm{~km}^{2}$ of land area would be needed to build a solar PV installation.

\subsection{Wind power}

Wind and solar energy are complementary on a day and seasonal scale. Wind and solar energy are complementary on a day and seasonal scale. Continental wind energy tends to peak at night, solar energy during the day, and solar panels generate little power in winter and stormy weather.

Onshore wind turbines have a generating capacity of 2-3 MW and offshore wind turbines have a generating capacity of approximately $6 \mathrm{MW}$. If all remaining electricity is to be provided by wind, and the intermittent nature of wind supply is also taken into account, the capacity factor is about half that of wind turbines in coalfired power plants by reducing the potential output. Therefore, at least 3752-5628 onshore wind turbines, or 1876 offshore wind turbines, plus storage capacity, would be needed to balance the fluctuations in supply.

\section{Conclusions}

For the same mass, burning oil releases $50 \%$ more $\mathrm{CO}_{2}$ than burning natural gas, while burning coal releases twice as much $\mathrm{CO}_{2}$ as burning natural gas.

Italy's per capita emissions of $\mathrm{CO}_{2}$ and $\mathrm{SO}_{2}$ are $30 \%$ higher than the world's per capita emissions, but Italy's per capita electricity consumption is $50 \%$ higher than the world's per capita electricity consumption. This shows that Italy has good use of renewable energy, and there is still room for development.

$\mathrm{CO}_{2}$ and $\mathrm{SO}_{2}$ from fuel combustion contribute to global warming and acid rain, etc.

Due to the climate conditions, the potential of solar energy in Italy is very high and is likely to be the dominant form of electricity generation in the future.

By 2050, Italy will have the potential to generate $100 \%$ of its electricity from renewable sources.

\section{Acknowledgments}

We are grateful to the National Science Foundation of China for awarding this study (Grant Nos. 42072180; 41772147; 41272147) and the Chinese Academy of Sciences Instrument Equipment Function Development Technology Innovation Project (Grant No. E0280101). And we especially appreciate the anonymous reviewers for their constructive comments and advices for the manuscript.

\section{References}

1. H. Yue, E. Worrell, W. Crijns-Graus, S. Zhang, J. Clean. Prod. 301,126978 (2021)

2. L. Cui, Y. Li, Y. Tang, Y. Shi, Q. Wang, X. Yuan, J. Kellett, J. Clean. Prod. 199, 359-368 (2018)

3. S. J. Davis, R.H. Socolow, Environ.Res. Lett. 9 (8), 084018 (2014)

4. E. M. Carlini, R. Schroeder, J. M. Birkebæk, F. Massaro, Electr. Power Syst. Res. 169, 74-91 (2019)

5. European Union, Directive No. 2009/28/EC of the European Parliament and of the Council of April 23 2009, on the Promotion of the Use of Energy from Renewable Sources and Amending and Subsequently Repealing Directives No. 2001/77/EC and No. 2003/30/EC (23 April 2009).

6. M. Antonelli, U. Desideri, A, Franco, Renew. Sust. Energ. Rev. 81, 3090-3100 (2018)

7. A. Cieplinski, S. D'Alessandro, F. Marghella, Renew. Sust. Energ. Rev. 142,110838 (2021)

8. C. Pelletier, Y. Rogaume, L. Dieckhoff, G. Bardeau, M. N. Pons, A. Dufour, Appl. Ener. 235, 1381-1388 (2019)

9. G. G. E. Patiño, F. N. Rivera, J. Clean. Prod. 208, 1118 (2019)

10. T. R. Anderson, E. Hawkins, P. D. Jones, Endeavour,40, 178-187 ( 2016)

11. World Meteorological Organization, WMO Statement on the State of the Global Climate in 2019. WMO-No. 1248. Geneva. ISBN 978-92-63-11248-4. (2020)

12. M. Stephenson, Energy and Climate Change: An Introduction to Geological Controls, Interventions and Mitigations. Elsevier. ISBN 978-0128120217 123-146 (2018)

13. Kavian, A. Alipour, K. Soleimani, L. Gholami, P. Smith, J. Rodrigo-Comino, Hydrol. Process. 33, 261270 (2019)

14. Y.Wang, R. Han, J. Kubota, Renew. Sust. Energ. Rev. 54,1182-1188 (2016)

15. M. Z. Jacobson, M. A Delucchi, G. Bazouin, Z. A. F. Bauer, C. C. Heavey, E. Fisher, S. B Morris, Piekutowski, Diniana J. Y, T. A Vencill, T. W Yeskoo, Energ. Environ. Sci. 8, 2093-2117 (2015)

16. Web.archive.org. Idroelettrico In Italia. [online] Available at: <https://web.archive.org/web/ 20121028011914/http://www.eniscuola.net/it/energi a/contenuti/idroelettrica/left/conoscere-idroelettrica /idroelettrico-in-Italia $>$. (2012)

17. GSE 2011. Statistical Report on Installations Using Renewable Energy (2010) Globalsolaratlas.info. Global Solar Atlas. [online]

18. Available at: $<$ https://globalsolaratlas.info/detail? $\mathrm{c}=41.557922,12.65625,5 \& \mathrm{r}=\mathrm{ITA}>\quad$ [Accessed 26 January 2021]. 